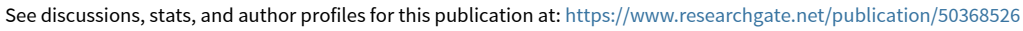

\title{
Relational Ontology: Being and Order Out of Heidegger's Socioontology
}

Article $\cdot$ January 2010

DOI: 10.1007/978-3-531-92402-1_12. Source: OAI

1 author:

(7) Patrik Aspers

2. University of St.Gallen

91 PUBLICATIONS 1,563 CITATIONS

SEE PROFILE

Some of the authors of this publication are also working on these related projects:

I am working on several issues, one is a major book on the reasons forms and consequences of evaluation and valuation View project

being and order View project 


\section{Relational Ontology \\ Being and Order out of Heidegger's Socioontology}

Patrik Aspers

\section{Introduction ${ }^{1}$}

This chapter addresses the question of ontology. It is an issue on which each scientific theory explicitly or implicitly has a position, as a theory comes with ontological assumptions. I will in this text show that the ontological question, nonetheless, has been neglected. My point is not to make a philosophical argument; instead, I approach the question of ontology by analyzing the more concrete question of order. How order is made and maintained are profound sociological questions. ${ }^{2}$ Social scientists have studied order, in terms of law and order, and how, for example, institutions, identities, organizations are socially constructed and "ordered" in relation to each other. Social scientists have also discussed the more profound epistemic level of order, or in other words, the ordering principles of things.

In this chapter I will take the analysis one step further and analyze the ontological level of order, which, as we will see, cannot be separated from the question of ontology. Social scientists who speak of "ontology," a notion with a less clear meaning in the English language that has come to dominate academia, normally refers to the epistemic problem of how to know about the world, but this world is assumed. As, arguably, all sociological theories make ontological assumptions, it is a surprise that even radical and agnostic sociologists have remained faithful Christians in one important sense. They have, as most social scientists, assumed the world to be there, not to be understood by means of an interpretative process in which we simultaneously get to know ourselves, but as something to be discovered by us. ${ }^{3}$ But the problem is even more severe: the social scientists are caught in an epistemic spell, and the discussion of realism and idealism are epistemologically framed (Heidegger [1927] 2001:183). It is always the question of how to get to know the world that is the focus, never the ontological conditions of this "knowledge-question". It is the latter question I want to study. To discuss the onto-

1 I am grateful for comments from conference participants, Sebastian Kohl, and especially Jan Fuhse and Sophie Mützel.

2 I have in other texts discussed the issue of order, and especially in relation to markets (Aspers 2007b; Aspers 2010; Aspers 2008).

3 At the time when sociology was formed as a discipline, ontology was not a central issue, and it never became central.

\section{VS Ventag tur soziehissenschaten}


logical level is a way of reflecting on how the social is constituted, and the conditions of social constructions. I claim that this will have consequences for how sociologists think, theorize and conduct empirical studies.

I start the chapter with the question of order, but this is merely the entry point to the discussion of how major sociological approaches assume ontological positions, though not making this a theme of reflection or analysis. Special attention is paid to relational sociology that is a promising social scientist approach. However, I show that also its leading thinker Harrison White operates with a traditional view on ontology. Relational sociology is nonetheless corresponding well with the relational ontology discussed in this chapter. To provide an ontological foundation Martin Heidegger's relational ontology is introduced, and I show how it is a useful ground for further discussions of the ontology of relational sociology.

\section{Starting with Martin Heidegger}

To analyze this central, but essentially forgotten, question of ontological order, I shall turn to the relational ontology of the German philosopher Martin Heidegger (18891976). Heidegger not only brought this question into light but also provided building blocks for an ontological analysis. By drawing on Heidegger, this chapter offers an ontological foundation for sociology. More specifically, it proposes a relational ontology that puts man and his relations to other men at the center. I call this socioontology. This paper starts from the assumption that a study of ontology is a way to provide us with a new foundation for sociology. We can thereby address the old question of order with a fresh look, by finally passing the episteme hurdle that has so far been insurmountable for social scientists. I offer a starting point that is essentially social: Man, or in other words the human being, is ontologically constituted as social. Consequently, man is an essential part of social order. In this way, the chapter provides a discussion of the foundation that is also televant for the other chapters in the book. Though this chapter can be nothing but a starting point of what may be studied by sociologists in the future, it contributes to our knowledge by addressing ontology. This contribution is the result of bringing Heidegger's thinking into sociological use, which is a too rare thing to do (Weiss 2001).

\section{Order Based on Taken-For-Granted Reality}

We have learned that the question of ontology is a task for philosophers, although even among them, this question has been seen as "metaphysical". Sociology is not philosophy, but sociology approaches social life based on ontological assumptions. To not jump directly to the ontological question, and to show why it matters for sociology, we start with the question of order. Order can be defined as the predictability of human acti- 
vities and the stability of social components in relation to each other (Hayek 1973:36). The question of order has been analyzed at three levels, the political, the social and the epistemic. I will briefly exemplify each of these.

The "political" level concerns how law and order is maintained. This is the question that Hobbes ([1651] 1968) posed. Hobbes assumed that men have certain traits, living in the state of nature, which they then use when "agreeing" on a rational solution-the creation of the state as the sovereign authority-to the benefit of all. Parsons has addressed order of society and its components as a social problem ([1951] 1970:4; Parsons [1937] 1968). To him the question of order is "solved" because of the cultural values that are reproduced in the socialization process. More concretely, actors' orientation to the norm system preserves order in society.

Both Hobbes and Parsons assume that there is a world existing out there, a position that we call realism (Parsons [1937] 1968:753-7). Parsons assumes that there is a firm "ontological base" which is never questioned, and frames the problem for the social sciences as an epistemic problem. Parsons describes his position as:

"realistic, in the technical epistemological sense. It is a philosophical implication of the position taken here that there is an external world of so-called empitical reality which is not the creation of the individual human mind and that is not reducible to terms of an ideal order, in the philosophical sense." (Parsons [1937] 1968:753)

This idea implies that the world, also the social world that we have made, is real, and exists independently of us as scientific observers. Parsons argues that scientific theories are not part of the world (Parsons [1937] 1968:753-754). This position he calls "analytical realism" (Parsons [1937] 1968:758). Realism implies that the world is "out there" and that the researcher, also the sociologists, should direct his attempt to investigate the world that is accessible in principle in the same way as the natural world is accessible to the natural scientists. The question for Parsons is social, and the epistemic question is merely a reflection of his ontological assumption of an independently existing world. ${ }^{4}$

Foucault ([1966] 2002) studies order at the epistemic level. His problem is about the different episteme, i.e., tacit assumptions that are the base for the principles of ordering the world. He talks of different epistemic regimes, each providing a scheme of how the world is. The focus lies on principles of knowing the world, as they determine how we order things; the world as such is not really the subject matter. Foucault's question is essentially about how to get to know the world, and he shows the different epistemic "discourses" that determine what is knowledge and the ways of gaining knowledge. This analysis does not really separate ontology from epistemology; each episteme comes with an idea of the world.

$4 \quad$ Fuhse has analyzed how network theorists have viewred man (Fuhse 2008). His study shows how relational sociologists have stressed how man is affected by his ties. Here I look at the assumption of how man is constituted, and more fundamentally, how man's constitution cannot be separated from the question of ontology.

\section{YS Yerag Tur Soziamsensehenen}


According to phenomenological sociology, order is to be understood at the level of meaning structure. What is the ontological foundation of phenomenological sociology, the most outspoken social constructivists approach? The roots of the most well-known social constructivists, Berger and Luckmann ([1966] 1991), are found in the works of Alfred Schütz. ${ }^{5}$ Schütz is clear about what is constructed and what is taken for granted:

"As we proceed to our study of the social world, we abandon the strictly phenomenological [Hussertian] method. [...] The object we shall be studying, therefore, is the human being who is looking at the world from within the natural attitude." (Schütz [1932] 1976:97-98)

Schütz explicitly states that we thereby have reached the ontological level: "it is our meaning of our experiences and not the ontological structure of the objects which constitutes reality" (Schütz 1964:230; 1996:36-38). This sentence implies two things: there is an ontological structure which is different from and independent of the meaning structure of people, and the scope of the social scientist is only the latter of these two, i.e., the meanings (cf. Theunissen [1977] 1984). ${ }^{6}$ One may, in line with Schütz' position, speak of ontological realism, and epistemic idealism. The key assumption of this "ontology" is that of the ego who tries to find out something about reality.

The important issue here is not that realism has been the most common assumption of social scientists, but that the question of ontology has never been discussed. I will in the next section turn to relational sociology, which is the focus of this book. This approach, as I will show, holds a key for entering the door to the ontological domain that hitherto has been essentially closed to, but more importantly by, sociologists.

\section{Order and Ontology in Relational Sociology}

How is the central question of order addressed by relational sociology, and what is the ontological assumptions of this approach? We may pose the question of order in the light of the relational sociological perspective as follows: what is the relation between social components, including "things" and humans? The father of modern network the-

5 Schütz' phenomenology, furthermore, is rooted in Husserl's monadological "ontology" (Aspers [2001] 2006).

6 Rational choice is yet another approach that starts with this "egological" assumption (Coleman 1990), which essentially means that the entire question of ontology is taken for granted, and the task of science is only to elaborate on how social relations are constructed. Actor Network Theory speaks of "actants" (for example, Latour 1996) and fails to see that a social "ontology" is rooted in human beings; it merely reduces humans to things. Some researchers, who use network "theory" more as a method, assume, in a similar fashion, that the only thing that matters is the form of contact, or the content of the form of relation that is of interest. The nodes, the actors, constitution, do not change. One may even say that positivism and its corresponding methods have generated a kind of ontological Gestell (Heidegger 1962) in which the world has to be there independently of us to legitimate these methods. My point is, that for some the epistemic conditions have primed their view on "ontology". This may be a sociological reason as to why the ontological question has not been raised.

\section{YS Verlag Tur Soziamsenschaten}


ory, Harrison White, is the most central thinker of "relational sociology" (Azatian 2003; Mützel 2009). Emirbayer (1997) identified a number of other sociologists, e.g., Pierre Bourdieu and also symbolic interactionists, who can also be called relational sociologists.

In this text, I let Harrison White represent the relational approach. See Fuhse (2009) and the other contributions to this volume for a more detailed discussion of the relational approach. White's most important book is called Identity and Control. It is published in two editions, the first with the subtitle $A$ Structural Theory of Social Action (White 1992), and the second with another subtitle Hozv Social Formations Emerge (White 2008). These two editions will be the main sources in this text for understanding and analyzing White on the question of order, and more concretely on the ontological foundation of this theory.

White is a structuralist who theorizes how to get action. Another central idea of White is that order emerges out of noise. White claims that his theory of social formations (disciplines), or social molecules, is a general theory, which operates at the so-called middle range level (White 1992:xii). He says that these disciplines, which are social formations, are the smallest units of analysis. They are, moreover, social constructions. White talks of three forms of social molecules: arena, interface and councils, but this is unlikely to be the final outline (cf. Azarian 2003:117-125, 185-187). Each of these disciplines evolve together with ordering (White 1992:28). Molecules are seen as "self reproducing" structural contexts, which sustain identities (Leifer/White 1987:85; White 1992:22). His analysis is centred on two concepts, identity and control. Identities are created as a result of interaction in the social molecules. Or as the second edition begins, "Identities spring up out of efforts at control in turbulent context" (White 2008:1).

Control efforts are made in relation to other identities, and this can only be understood in relation to the "contingencies" that the identities imply. For a single identity, other identities make up the social reality, which it more or less has to take for granted. An identity is defined as "any source of action not explicable from biophysical regularities, and to which observers can attribute meaning" (White 1992:6). One identity, and one identity's emergence, can only be understood in relation to other identities, their emergence and existence.

Identity, rather than persons, which White (1992:24) sees as a myth, or organizations is the starting point of the analysis. Persons, including the associated components, preference and goals, are derived from social actions, rather than being the cause of these actions, as the myth of tational choice theory tells us (White 1992:8). White, nonetheless, focuses on the "personal" identity, which is the result of actors switching between different netdoms (White 2008:7). He argues that persons come into "existence and are formed as the result of overlaps among identities from distinct network populations" (White 2008:129). This is a form of "passive" identity formation, in which one identity can only be understood as a result of other identities (and their need to control). An identity evolves in social interaction; it is here that the most central idea of "relation- 
al sociology" appears in White's thinking. Identities and ties emerge together, and ties make up networks. Ties and identities are inseparable, though ties can be direct or indirect (White 2008:20-36). Identities can, moreover, couple and decouple from a network. This means that one is taking part as coupled, and stop taking part (for the time being) by decoupling. Thus the tie remains after decoupling, which presupposes coupling (White 2008:36). There is consequently an essential relation - the tie - that is constitutive of identities.

How does this Whitean approach apply to the concrete fields that he has studied? In his sociology of markets, to take one example, actors watch each other, and it is the relational structure of a "dozen or so" actors who constitute each other's identities as a result of their interaction with the consumers (White 2002; Aspers [2001] 2006; Aspers 2010). White defines markets as "self-reproducing social structures among specific cliques of firms and other actors who evolve roles from observing each other's behavior" (White 1981:518). Each firm focuses on holding a niche in its own market, which it does in relation to other firms, some of which become known as high-quality producers, whereas others tend to be low-quality producers, who sell their product for less money (White 1993:162). Market order, to follow this argument, is a result of identities stabilizing in relation to each other. But what is the ontological foundation of this theory? To analyze this question takes us back to the issue of ontology and relational sociology.

More specifically, I address the following question: To what extent has White a "relational ontology"? In other words, on which implicit assumptions does relational sociology rest? In pursuing this question, I begin with the notion of identity. What does identity in White's theory presuppose ontologically? Remember, we are not here asking what identity "is", this we have seen. We try to figure out the ontological foundation of "identity" in White's theory. The following quotation suggests an answer: "[W]ithout footing, identities would jump around in a social space without meaning thus without communication" (White 2008:1). White claims that footing is the result of control projects by the identities. Though I actually believe that White, if pushed, would say that these "identities" are not identities, or not "real identities," the quotation nonetheless reveals what I see as a non-relational ontology. In other words, the assumption is that somehow the "non-social identities" - though this is a contradiction in terms - start to interact, and out of this, some order is generated that creates social contingencies, relations and thereby stabilized identities. In yet another terminology, before we can speak of identities there are monads that are jumping around, and only in a process of interaction do they become social (identities).

It is, according to White, the "chaos and accident" that are the "sources and bases of identity" (White 1992:4). One must, however, ask what it means to start with this original situation of noise or chaos, out of which identities, social structure, meaning, and eventually order emerges. What does it presuppose? White analyzes, though "for

$7 \quad$ White operates with several "senses" of identity. Though they are not by definition tied to human beings, White, "for simplicity," discusses them as "tagged to individual beings" (White 2008:10).

\section{Ys Verag Tur Sozidwissenseheten}


simplicity" "identities as tagged to individual human beings" (White 2008:10). So apparently, something is tied to the pre-existing and, I assume, atomistic units called humans. My interpretation of White's approach is, that these pre-existing units are endowed with meaning. In this way, we see the same non-relational ontological assumptions that are common in many different sociological approaches, also as the underlying assumption of relational sociology.

My point, to conclude this section, is that the abovementioned approaches, including White's, are based on ontological assumptions, but none of these discuss them explicitly. Man is assumed, and so is the rest of the world. Harrison White has, without doubt, a relational sociology, but it is less clear if there is a relational ontology. In my view, the relational approach lacks an ontological foundation that would correspond to a relational sociology, and that would see relations as essence, in contrast to man. It is thus correct to say, that in sociology, the

"question of order...concerns the ultimate source of social patterns; it does not concern the ontological question of whether these patterns or the individuals who may or may not support them are real" (Alexander, et al. 1987:13).

The problem with this is that sociologists only reduce ontology to epistemology, as too many do (Reed 2008). This may partly be because sociologists have never fully understood the character of the question, as our tools block us from posing it, and make us unable to even realize that this is an important question.

\section{The Regional Ontology of the Social Sciences}

My argument so far is that even among social constructivists the idea of ontology, and what it means, is underdeveloped. None of the approaches discussed so far, regardless of their "ontological" assumptions, has discussed the ontological level. These different sociological strands, instead, deal with the epistemic problem of taken for granted egos who try to know the wotld and who interact with other egos. They are not concerned with the ontological level. The central issue here is not tealism or idealism, though sociologists seem to become realists when faced with this problem. The central point is that there has been no real discussion of ontology. But before we turn to the question of ontology, let us look at a philosopher who tries to solve the social science problems.

The realism, to which many sociologists adhere, is essentially the same kind of social constructivism with a realist base that John Searle (e.g., 1995; 1998a; 1998b; 2005) 
tries to re-label and re-sell to the social sciences by making claims of contributing to the philosophical foundation of the social sciences. ${ }^{8}$ Searle's realist position takes virtually everything that is seen as knowledge according to the natural sciences as valid. $\mathrm{He}$ speaks of "brute facts" of the natural sciences that cannot be questioned. Ultimately, "the world" is part of what we cannot question. I fully agree with Waldenfels's view on Searle's contribution:

"Although Searle likes to pretend that what others like Berger and Luckmann did is totally different from what he is doing himself, he frankly promises to solve a lot of traditional questions by using new tools." (Waldenfels 1998:160)

I see Searle's work as evidence for my point that sociologists operate with a taken for granted ontology, which often rest on the realist position, i.e., a form of "every-day ontology" that is the basis for essentially epistemic questions. So, though I agree with Searle, that "unless you have a clear conception of the nature of the phenomena you are investigating, you are unlikely to develop the right methodology and the right theoretical apparatus for conducting the investigation" (Searle 2008:443-444), Searle stops the analysis long before it even gets interesting. In other words, sociologists, and also wellknown analytic philosophers like Searl, have not addressed the ontological level of order, as they have not analyzed the ontological level at all. At this point the reader may ask what ontology is, as it seems as if no social scientists have addressed it.

To get off ground, each individual discipline, including the social sciences, had to define a field of study that often corresponds with assumptions of the world. These ontological assumptions of the various disciplines constitute their regional ontologies (Husserl [1952] 1980:22; Husserl [1913] 1962:57), and we have seen that sociologists operate with surprisingly similar ontological assumptions, even though they disagree on many other issues. This means that we can, in fact, speak of one regional ontology of sociology. This "reality" has some particular characteristics, and it is to be investigated by egos who gradually open themselves up to the world around them (Heidegger [1927] 2001:206-207). This reality is only seen as something that is there to be discovered by an external observer - the knowing subject. I have shown that this is the case of the most central question in sociology - the question of order - which has never been asked as an ontological question. The main point, to repeat, is, that these approaches assume that there is a world that the knowing ego is trying to get knowledge about, thereby reducing the question to an epistemic problem.

The level sociologists call "ontology" is the level that Heidegger calls ontic, and it refers to what an individual discipline presupposes. Consequently, the ontic level refers to the "regional ontologies" of disciplines like sociology. But to clarify this, and to get a

8 This is also the case of the British movement called "critical realism". This movement, spearheaded by Roy Bhaskar ([1975] 1997) has developed a pbilosopbical ontology that essentially is about the conditions of the "world" that must be present for us to do research. Again, the ontological question is framed as an epistemic problem.

\section{VS Verae Tur Sozlamisenschaten}


better understanding of ontology, and perhaps also to provide sociology, or at least relational sociology, with an ontology, the next section turns to the philosopher who has discussed and analyzed the ontological question more than any other thinker, namely Martin Heidegger. Heidegger is used to address the two questions that we confront. The first is to clarify the ontological question, and the second is to see if relational sociology, and sociology more generally, could make use of Heidegger's work on ontology.

\section{Heidegger on Ontology and Man}

In this section, I will briefly explain Heidegger's ontological position, which I see as potentially useful for relational sociology. ${ }^{9}$ Ontology, the study of being, is the central question in Heidegger's most important work Sein und Zeit (Being and Time) (Heidegger [1927] 2001). More specifically, Heidegger's purpose is to clarify and pose the question of the meaning of being. What does it mean to say that something "is"? He argues that this question is forgotten and has essentially been covered up by the "ideas", in the broadest sense, we have developed since the time of the great Greek philosophers. We are today left with an "ontology" that is trapped in a Cartesian "subject-object" relation. That our thinking is deeply rooted in the Christian and Western-Christian thinking is beyond doubt. Heidegger has analyzed in detail the precondition of the Cartesian approach to "the world". Descartes, according to Heidegger, has provided the foundation for the idea that there is a human-independent world, and to that connected the epistemic problem. This serves as a fundamental level (Sicht) on which values and other social and cultural meanings are ascribed (Heidegger [1927] 2001:98-100). This is also the foundation on which the positive sciences, such as psychology, biology and sociology, are founded (Heidegger [1927] 2001:49).

Sociology has contributed, though essentially without reflecting upon this matter, to covering up the ontological question. I fear that one reason why sociologists have said so little on ontology, or simply reduced it to epistemology, is because the question has been misunderstood. What, then, is ontology?

The most general definition of ontology is the study of being, i.e., what there is (Heidegger 1988:1). This is not the study of particular "things", such as the objects of social sciences, ot even what they "are" (constitution or essence); it is more the conditions of these "ontic" statements that constitute the matter of ontology. Heidegger's own analysis can shed further light on the question. He begins Being and Time by analyzing and

$9 \quad$ Emirbayer (Emirbayer 1997) discussed the relational approach, but he does not mention Heidegger. In a later text he wrote with Ann Mische, Heidegger is mentioned, but only to introduce the notion of care (sorge), and not the more fundamental idea of relation (Emirbayer/Mische 1998:986-987) The most likely reason is that Heidegger is not well-known by sociologists. Heidegger has sometimes been compared with pragmatist thinkers, though this is not correct (Frede 2006:65-66), as they reduce ontology to epistemology (Malhotra 1987). This is not to deny that there is some similarity when it comes to ideas of "action".

\section{Y Verlag Tur Sozimissenschefem}


commenting on the question itself. To analyze ontology one cannot build on the existing theories, as they are part of the problem (Heidegger 1994:109-114). Heidegger suggests that phenomenology is the only suitable approach for understanding this basic question.

Heidegger's method is phenomenological-hermeneutical and it can be divided into three steps, reduction, construction and deconstruction. Reduction means to go back to the question of being, construction refers to the study of being, and deconstruction refers to the starting point of the analysis (Heidegger 1975:28-31). Destruction does not mean to destroy, but to take apart ( $A$ bbau). The process starts with our conception (preconception) of what we are interested in. This will take us to the phenomenon. Heidegger does not want to deconstruct ontology, but the historically produced doctrines of being ([1927] 2001:22-23); deconstruction is a concrete way of doing this (Heidegger 1994:118). ${ }^{10}$

According to this hermeneutical method, "man," human being, or what he calls Dasein, is the center of the analysis. Dasein has a special role, not as being outside the world that it tries to discover, but as being in this world. Dasein is the condition and the root of the fundamental ontology upon which all other ontologies rest. Man is thus at the centre of the analysis. To analyze "the world" without including man is nonsense. Man is in the world, and cannot be thought of as living "outside" this world (which is a presumption of the Cartesian subject-object distinction). It is, consequently, not the case that man first opens up a window to the world, reaches out, and builds a relation with the "atoms," "monads," or "egos" who are also reaching out from their "houses" (Heidegger [1927] 2001:81)." In fact, the idea of "ready-made" units who, somehow are there and become social at the same time as they create a social world, is an idea that many Western social scientists have taken over from Descartes, Leibniz and Husserl.

Heidegger sees things in a radically different way, and he addresses the ontological problem. He starts with the fundamental ontology of man, which is the baseline of other ontologies, such as those of the individual sciences. He makes clear that there is no naked subject (Heidegger [1927] 2001:116). Heidegger starts, in contrast, from the idea of what he calls Being, or in German, Dasein ("Dasein"=being there). Dasein is no strange creature, but what we are; it is mine (Heidegger [1927] 2001:114). Dasein is characterized by its "reflexive capacity," which is to say that Dasein also tries to understand itself (Heidegger [1927] 2001:86). That man, according to Heidegger, is already in the world (Heidegger [1927] 2001:53-60) implies that is conditioned by the relational web in which Dasein is positioned. Man is from the very "beginning" part of a larger whole, the

10 The historically created understanding, that is what we call tradition and "knowledge" has its roots in Greek thinking, on which later developments were built. Thus, our contemporary understanding is built on old ideas as well as taken for granted logical principles (Heidegger 1994:16-17). Also theology is built on historical ideas of being, and theology has stressed the idea of "substance" (Frede 2006:45).

11 Heidegger's approach is distinctly different from Hussetl's. Husserl stresses the role of mental acts and the constitution of meanings as the foundation for what we see as the world (Srubar 2001:178179). 
world (Heidegger [1927] 2001), and, eventually, everything is related back to man; man is the phenomenological and ontological starting point. Put in a different language: $\mathrm{Da}$ sein refers to himself, directly and indirectly, and is capable of asking questions of itself.

Heidegger presents a holistic idea; man is in the world, together with people and tools. The form of constitutive relation that is special to humans is called existential (not to be mixed up with existence) (Heidegger [1927] 2001:44-45), and this refers to the question "who?" (is there / does something). Humans have a form of being that is, as indicated above, more profound than "objects", as only man is capable of reflecting and he is also the condition to which all tools and activities finally are teduced (Heidegger [1927] 2001:86-87).

Heidegger presents the world as a hermeneutic unit. The man-world relation including the system of relations of the different tools that are in the world, Heidegger says, is prior to the single tools (Heidegger [1927] 2001:84). We only understand a tool, like a hammer, in its context. Heidegger, thus, presents a holism of how things are used (Bewandtnisganzbeit). But this is not merely a set of related "objects"- these tools (Zenge) that we use should be understood in relation to Dasein. These tools are ready-to-hand (Zubanderi) and refer to the question "what?" (Heidegger [1927] 2001:84), in contrast to existentials. The relation of the tools are called categories, and they are not essentials of Dasein.

Let us look more carefully into the "tools." They are only "discovered" by Dasein as a result of what it does. ${ }^{12}$ Heidegger is not propagating the Kantian idea that we discover the "things" as existing independently of people; in fact, the idea of "thing" in the Kantian way does, strictly speaking, not apply in Heidegger's theoretical work. Objects are not there before Dasein is there, but are constituted by the relation to his fellow men and other "things" that also are in the world. We have, as indicated, to do with a whole: each tool refers to another: the hammer to the nail, to the painting that hangs on the nail on the wall, which refers to the person who views it. Moreover, what is present-athand (Vorbandern), and what typically stands in the search light of any science, like stones, trees and so on that are part of the environment (Unmelt), is only "discovered" indirectly through what is close to, and practically known by, us, or what Heidegger calls ready-athand (Zuhanden). The trees in the forest that are used to make fire in the stove, as timber for the construction of the barn in the field, or for pulp to be sold for money. It is this that puts them in a meaningful whole. The fields of the farm, as its tractor, as its forest with its woodcutting roads (Holzperege) - including the one with the stone that is too big for tractor to overcome - are all related to each other. Furthermore, the field and the forest belong to the owner of the farm, and the farmer cultivates the land. The farm is adjacent to another farm, but it is not the physical proximity, but the relation to the owner - regardless whether he or she is known to us - that makes it a relation to others. This "Zengrusammenbang" or wholeness of our surrounding world (Umwelt) of tools in a wide sense, suggests that one shall not see "things" atomistically, or as existing prior to

12 Heidegger claims that man, in his everyday-life, understands himself by what he does (Heidegger [1927] 2001:239).

\section{VS Verleg fur Sozimissenschefen}


Dasein. We understand them because of their system usefulness in which they refer to each other (Heidegger [1927] 2001:85-88). Moreover, as indicated in the examples, what we have around us refers to other humans' activities, though we may not know them as individuals. It nonetheless refers to others (Heidegger [1927] 2001:117-118). One may say that the world is essentially a social world, in which what we have around us refers to our Mitseins (being-with other people). ${ }^{13}$

So far, I have discussed man's relation to things, and only indirectly discussed the relation to other men. However, the world is essentially a world with others (Mitwelt) (Heidegger [1927] 2001:118). The other is not always represented by a concrete individual. There is, according to Heidegger, an existential relation between Dasein and others who are also there (Mitsein). Individuation and individual perceptions, ideas and so on, if I am correct, are, however, only derivatives of the "social world" that constitute our being (Heidegger 2001:334). Heidegger, as we have seen, argues that man is not an island. In fact, man, or Dasein, is only possible as a relation with others (Heidegger 2001:333; [1927] 2001:125). Thus, we cannot, "even make sense of a non-social Dasein" (Dreyfus 1991:148). Dasein, as I have said, is not a subject, and Heidegger, in trying to make his point clear by using a Cartesian language, sees it as "between" subject and object (Heidegger [1927] 2001:132). But he, of course, means something more than that Dasein is "in between" two existing things in a Cartesian space. The theories of "subject-objectrelations" that have framed so much of the sociological discussion, is in Heidegger's view a result of Dasein. It is one ontic possibility among many, but this relation is not basic, and cannot account for the ontological question. It is, as it were, an ontic question. The "in-between", to try to explain Heidegger's position in a non-Heideggerian langulage, is the constitutive relation, not the "objects". For Heidegger, distances and positioning are derivates of the phenomenological notion of being there, and the distance correlates with Ferne ("far away") and "Näbe" ("close by"). Consequently, to be in-the-world is essentially to be in the wotld with others. Although a car is also in-the-world, it has a different relation to Dasein than Dasein has to its Mitseins.

We will now take a closer look at the "social" dimension of Dasein. Dasein, to further separate it from the more common idea of "subject" is dispersed (zerstreut) and must find itself (Heidegger 2001:333). Not only is Dasein ontologically dispersed, it is also dispersed and fragmented in its own activities: caring (sorgen) for something, doing something, questioning and other kinds of activities (Heidegger [1927] 2001:56-57). This idea of dispersion corresponds to what White says about how persons are constituted due to multiple identities in several domains. What Heidegger says is not that Dasein first is a unit that then falls apart, it is rather the other way around: the dispersion is the condition of the unity of man. Heidegger says moreover, that one is given to one self (Heidegger [1927] 2001:129). The "subjective" feelings, empathy and much more are only derivatives of the more basic Mitsein relation. Heidegger says that the "I-You" as

13 One may here discuss the relation to the Actor-Network-Theory (e.g., Latour 1996). But Heidegger sees practice as being prior to mental knowledge.

\section{VS Verlag Hur Soriamisenshenten}


well as the sex-relation presupposes the we-relation of Mitsein (being with) (Heidegger 2001:145-146). It is only because we first are together that we can be alone. This idea summarizes the ontological condition, which is directly the opposite of the "egological" positions that we discussed in relation to the sociological theories, and which state that man starts out alone, and then becomes social. ${ }^{14}$

Although the idea of relations between man and the world is essential, one must see how it connects to what sociologists usually find to be highly interesting, the idea of das Man (They). The others, not necessarily in a concrete way, are what make up das Man (they). To be with others does not call for direct presence of people. Heidegger is, in contrast, stressing how we are affected by what "one does" or what das Man does. The normative priming is for Heidegger not something that enters the "inner sphere" of the subject, as he rejects this idea; it is an essential relation. Each of us is part of they, but they are always there; one behaves as "one does," reads newspaper as one does, enjoy oneself as one does and so on. Das Man constitutes the public and Heidegger even uses the notion of dictatorship to account for the relation between the one and the many, in a way that resembles Nietzsche's view (Aspers 2007a). It is important to see that Heidegger does not only focus on the direct relations, but argues that we are tied up with social norms. Our thinking and practice, or for short, being, is constituted in relation to social practice and conventions (Heidegget [1927] 2001:126-130). Das Man is part of the constitution of Dasein, and Dasein is dispersed "in" das Man. I will not here discuss Heidegget's analysis of authentic life, and the relation of this to das Man. The main point from the perspective of this chapter is, that Heidegger addresses the ontological level. This level cannot be understood unless one starts with man who is already in the world-Dasein, reflecting the fundamentally relational ontology of Heidegger. A more detailed study should be done to further outline and analyze Heidegger's position in telation to relational sociology.

\section{Conclusion and Outlook}

The ontological question is not addressed in sociology. This is despite the fact that all sociological theories make ontological assumptions. This issue has often not even been acknowledged, which may be due to sheer ignorance. This chapter has studied the ontological level. I started with the question of order, and saw that sociological approaches, the relational approach included, have a non-relational ontology. In fact, the every-day ontology is taken for granted, upon which meaning is bestowed in social processes. This is to say that the ontological level is left out in social science analyses. To address this question of ontology we turned to Martin Heidegget, who analyzed it in detail.

14 Berger and Luckmann as well as Mead, represent, when their theories are boiled down to their ontic assumptions, egological approaches, though they in practice are much more oriented to a social constitution.

\section{VS Verlag fur Soziamissenschamen}


Heidegger's position puts man at the center, but it also suggests that there are a number of essential relations before one can speak, at all, of man (Dasein). Man is, in a different language, essentially social. This position, what I call socioontology, represents a radically different idea than what has been common in sociology and other social sciences, most notably economics, namely that man is ontologically isolated and only through processes does he reach out and become social. Heidegger is remarkably radical as he says that to talk of "man" as non-social is nonsense. This sociological idea must be seen in the light of Heidegger's fundamental ontology program. Instead of taking the world for granted, as being there to be discovered by a knowing subject - which is to reduce the ontological problem to an epistemic problem - Heidegger offers us a fundamental ontology centered on man. From the discussion of Heidegger's work it follows that one can "apply" his findings to understand the ontological level, and even perhaps also in a more relaxed and pragmatic way. Heidegger's position tepresents a critique of neoclassical economics and rational choice, and others that propose a non-social foundation.

Heidegger's ontological work is not directed at the specific problems of the individual sciences (Srubar 2001:184; Heidegger [1927] 2001:312-313). This should not stop us from finding ideas in Heidegger's text that can help us to improve sociology. In this chapter, I have tried to draw on Heidegger's analysis of ontology, and shown how it is relevant for relational sociology. I argue that Heidegger's idea of das $M$ an and being-together-with-others, the importance of "in between," the deconstruction of the subjectobject relation, the rejection of mentalism, and much more can be used for developing sociology. More specifically, sociologists who speak of social constructions (Hacking 1999), following Berget and Luckmann (Berger/Luckmann [1966] 1991), must account for the fact that also people's identities are "social components" that have to be ordered. Social order is special as man is both ordered and, at the same time, the reason for us talking of order at all. Man, one may say, holds a special role as both part of the world but with the capacity to reflect upon herself (cf. Heidegget [1927] 2001:25). Sociologists must therefore approach the notion of identity, and more explicitly human identity, with special attention, as the very idea of order only makes sense in relation to human activities. Man is, in other words, not an object among others, as relational sociologists have made clear (Mützel 2009).

Heidegger discusses the "relation" and the "constitution" of Dasein, and he thereby presents a fundamental ontology, which I have tried to show has a strong relational base. This can be the starting point for further development. The relation to others, not the least in forms of ties, as well as the indirect relation to man via human-made tools, could also be discussed much more in the light of Heidegger. Heidegger's relational socioontology is a new way of thinking of social relations. He outlines several different kinds of relations, but also a method for understanding of man. This method of understanding, the hermeneutic (Heidegger 1988), is everything but psychological, it is ontological, or as I have said, socioontological. The larger task of employing Heidegger's ideas, however, has not been pursued here; this is a task for the future.

\section{VS Veriac fur Sozianisenseheten}




\section{References}

Alexander, Jeffrey , et al. (eds.), 1987: The Micro-Macro Link. Berkeley: University of California Press. Aspers, Patrik, [2001] 2006: Markets in Fasbion, A Pbenomenological Approach. London: Routledge. Aspers, Patrik, 2007a: Nietzsche's Sociology. In: Sociological Forum 22, 474-499.

Aspers, Patrik, 2007b: Wissen und Bewertung auf Märlkten. In: Berliner Journal fïr Soziologie, 431-449.

Aspers, Patrik, 2008: Order in Garment Markets. In: Acta Sociologica 51, 187-202.

Aspers, Patrik, 2010: Orderly Fashion: A Sociology of Markets. Princeton: Princeton University Press.

Azarian, Reza, 2003: The General Sociology of Harrison White. Stockholm: Department of Sociology, Stockholm University.

Berget, Peter/Thomas Luckmann, [1966] 1991: The Social Construction of Reality, A Treatise in the Sociology of Knowvledge. London: Penguin Books.

Bhaskar, Roy, [1975] 1997: A. Reatist Theory of Science. London: Version.

Coleman, James, 1990: Foundations of Social Theory. Cambridge, Mass.: Harvard University Press.

Dreyfus, Hubert, 1991: Being-in-the-IWorld, A Commentary on Heidegger's Being and Time, Division 1. Cambridge: The MIT Press.

Emirbayer, Mustafa, 1997: Manifesto for a Relational Sociology. In: American Journal of Sociology 103, 281-317.

Emirbayer, Mustafa/Ann Mische, 1998: What is Agency? In: American Journal of Sociology 103, 962-1023.

Foucault, Michel, [1960] 2002: The Order of Things: An Archaeology of the Human Sciences. London: Routledge. Frede, Dorothea, 2006: The Question of Being: Heidegger's Project The Cambridge Companion to Heidegger. Cambridge: Cambridge University Press, 42-69.

Fuhse, Jan, 2008: Menschen in Netzwerken. In: Karl-Siegbert Rehberg (ed.) Die Natur der Gesellschaft. Frankfurt/Main: Campus 2933-2943.

Fuhse, Jan, 2009: The Meaning Structure of Social Networks. In: Sociological Tbeory 27, 51-73.

Hacking, Ian, 1999: The Social Construction of What? Cambridge Mass: Harvard University Press.

Hayek, Friedrich von, 1973: Lam, Legislation and Liberty, A Nens Statement of the Liberal Principles of Justice and Political Economy, Volume 1, Ruter and Order: Chicago: The University of Chicago Press.

Heidegger, Martin, 1962: Die Tecbnik, und die Kebre. Pfullingen: Verlag Günther Neske.

Heidegger, Martin, 1975: Die Grundprobleme der Phänomenologie, Gesantansgabe, II. Abteilung, Vorlesungen 19231944, Band 24. Frankfurt am Main: Vittorio Klostermann.

Heidegger, Martin, 1988: Ontologie. Hermeneutik der Faktizität, Gesamtausgabe II. Abteilung: Vorlesungen 19191944, Band 63. Frankfurt am Main: Vittorio Klostermann.

Heidegger, Martin, 1994: Einfilbrung in die phänomenologische Forschung, Gesamtausgabe, II. Abteilung: Vorlesungen 1919-1944, Band 17. Frankfurt am Main: Vittorio Klostermann.

Heidegger, Martin, 2001: Einleitung in die Philosophie, Gesamtausgabe, II Abteilung: Vorlesungen, Band 27. Frankfurt am Main: Vittorio Klostermann.

Heidegger, Martin, [1927] 2001: Sein und Zeit. Tübingen: Max Niemeyer Verlag.

Hobbes, Thomas, [1651] 1968: Leviatban. London: Penguin Books.

Husserl, Edmund, [1913] 1962: Ideas, General Introduction to Pure Pbenomenology, Book I. New York: Collier Books.

Husserl, Edmund, [1952] 1980: Ideas, Pertaining to a Pure Phenomenology and to a Phonomenological Pbilosophy, Book III, Phenomenology and the Foundations of the Sciences. The Hauge: Martinus Nijhoff.

Latour, Bruno, 1996: Aramis or the Love of Tecbnology. Cambridge: Harrard University Press.

Leifer, Eric/Harrison White, 1987: A structural approach to markets. In: M Mizruchi/M Schwartz (eds.), The Structural Analysis of Business. Cambridge: Cambridge University Press, 85-108.

Malhotra, Valerie 1987: A Comparison of Mead's 'Self' and Heidegger's 'Dasein': Toward a Regrounding of Social Psychology. In: Human Studies 10, 357-382.

Mützel, Sophie, 2009: Networks as Culturally Constituted Processes, A Comparison of Relational Sociology and Actor-Network Theory. In: Current Sociology 57, 871-887.

Parsons, Talcott, [1951] 1970: The Social System. London: Routledge.

Parsons, Talcott [1937] 1968: The Structure of Social Action. New York. 
Reed, Isaac, 2008: Justifying Sociological Knowledge: From Realism to Interpretation. In: Sociological Theo1y 26, 101-129.

Schütz, Alfred, 1964: Collected Articles II, Studies in Social Theory. The Hague: Nijhoff.

Schütz, Alfred, [1932] 1976: The Phentomenology of the Social World. London: Heineman Educational Books. Schütz, Alfred, 1996: Collected Papers IV. Dordrecht: Kluwer Academic Publishers.

Searle, John, 1995: The Construction of Social Reality. New York: Free Press.

Searle, John, 1998a: Mind, Language and Society, Pbilosopby in the Real World. New York: Basic Books.

Searle, John, 1998b: Social Ontology and the Philosophy of Society. In: Analyze und Kritik 20, 143-158.

Searle, John, 2008: Language and Social Ontology. In: Theory and Socieby 37, 443-459.

Searle, John 2005: What is an institution? In: Journal of Insititutional Economics 1, 1-22.

Stubar, Ilja, 2001: Heidegger und die Grundfragen der Sozialtheorie Die Jemeinigkeit des Mitseins, Die Daseinsanalytik Martin Heideggers und die Kritik, der soziologischen Vernuft. Konstanz: Verlagsgesellschaft mbH., 175-195.

Theunissen, Michael, [1977] 1984: The Other; Studies in the Social Ontology of Hurserl, Heidegger; Sartie, and Buber: Cambridge, Mass.: MI'T Press.

Waldenfels, Bernhard, 1998: Comment on John Searle's 'The Construction of Social Reality. In: Analyse o Kritik 20, 159-165.

Weiss, Johannes, 2001: Einleitung. In: Johannes Weiss (ed.) Die Jemeinigkeit des Mitseins, Die Daseinsanalytik Martin Heideggers und die Kritik der soziologischen Vernuft. Konstanz: Verlagsgesellschaft mbH., 11-56.

White, Harrison, 1981: Where do Markets Come From? In: The American Journal of Sociology 87, 517-547.

White, Harrison, 1992: Identity and Control, A Structural Theary of Social Action. Princeton: Princeton University Press.

White, Harrison, 1993: Markets in Production Networks. In: Richard Swedberg (ed.) Explorations in Economic Sociology. New York: Russel Sage Foundation, 161-175.

White, Harrison, 2002: Markets from Networkes, Socioeconomic Models of Production. Princeton: Princeton University Press.

White, Harrison, 2008: Identity and Control, How Social Formations Emerge. Princeton: Princeton University Press. 